\title{
Sports Club Employees' Psychological Contract Structure and Its Influence on Job Satisfaction
}

\author{
Qing-xuan ZENG ${ }^{1,{ }^{*}}$ and Liu HU² \\ ${ }^{1}$ Tianjin University of Sports, 51 Weijingnan Road, Hexi District, Tianjing,P.R.CHINA \\ ${ }^{2}$ Wuhan Business University, 816 Dongfeng Road,Wuhan,P.R.CHINA \\ *Corresponding author: steng1984xx@163.com
}

Keywords: Sports fitness club, Employees, Psychological contract, Job satisfaction.

\begin{abstract}
With integrated use of literature review method, interview method, questionnaire survey and mathematical statistics, the study selected 60 members of six sports fitness clubs such as Mountain Sports Fitness Club of Wuhan, Dongxihu Youth Sports Club as the research object. According to the results of this study, the item sets and content structure of the "Organization Responsibility Questionnaire" and "Employee Responsibility Questionnaire" of the Sports Fitness Club Employee Psychological Contract Questionnaire we compiled is reasonable; "Responsibility" has a significant positive correlation with the employee pay satisfaction, promotion satisfaction, satisfaction, management satisfaction, interests satisfaction, reward satisfaction, colleague satisfaction, satisfaction of the job itself and communication satisfaction, and negative correlation with operating procedures satisfaction; Organizational responsibility impact on employee job satisfaction is mainly manifested in the "economic transactions responsibility", " interpersonal relationship responsibility", "career development responsibility". These three dimensions are not identical.
\end{abstract}

\section{Introduction}

The development of the sports fitness club has important significance on the promotion of the national fitness program, rich amateur cultural life, and the physical improvement. Domestic research on sports organizations mainly research two aspects in the organization research and club research, in which most of organization structure are the internal organization structure, such as organization structure, membership, etc. As a new industry, sports fitness club has the outstanding characteristics of its profit-making, at the same time innovative management is needed to healthy development. And the result of innovative management is bound to be management innovation. Different from the traditional management, innovative management has innovation throughout the entire process, and the management change with the technology, market and environment changing. In the innovation management of the people-centered health club industry, managers improve the work performance management by changing the club staff's attitude and behavior modification. Innovation is the guarantee of victory in the competition and maintaining of competitive advantage.

Club operators (managers) have been clearly aware of the fact that "talent is the key factor to determine the level of organization". So, how to attract and make use of excellent human resources and more importantly, how to fully motivate employees, make them happy and dedication in the club are considered. In fact, if you want to attract and use of talents and cultivating the staff's professional spirit, the most basic condition is to understand their expectations and requirements of the club, to 
understand their ideas of values. Only by dong this can we make the feasible human resource policy, make the right and reward of the employees equal to their responsibilities and obligations as much as possible, and better use the enthusiasm of employees. Employees' psychological contract research provides a new starting point for us to understand employees' perception of both sides mutual responsibility, expectations and promise from a new angle.

\section{The Research Object and Methods}

In the questionnaire (prediction), survey objects are 60 members selected from Elaine Fitness Club, Dongxihu Youth Sports Club, Yingpaisi fitness club, Paffic fitness clubs and evergreen fitness club. In discussing three dimensions of the employees' psychological contract, the economic trade liability responsibility, career development and interpersonal influence on job satisfaction, we use the revised Sports Fitness Club Employee Psychological Contract Questionnaire and Work Satisfaction Survey. The questionnaire objectis same as the previous one.

\section{The Results and Analysis}

\section{The Sports Fitness Club Employees' Psychological Contract Structure}

Compiling of the Sports Fitness Club Employees' Psychological Contract Questionnaire. The sports fitness club employees' psychological contract questionnaire of this research includes two parts. They are club (organization) responsibility and employees' responsibility. According to the factor loading situation, this research deleted the low load in the corresponding entry in the six subjects $(Z 7=$ $0.297 ; \mathrm{Z} 5=0.363 ; \mathrm{Z} 13=0.348 ; \mathrm{Z} 14=0.213)$. After factor analysis of the revised questionnaire on the remaining item, factor loading were greater than 0.45 level. We believe the overall effectiveness of the forecasting questionnaire "organization for the employee shall bear the responsibility" is acceptable. At the same time, this study made questionnaire confirmatory factor analysis for the forecast of staff responsible In the "employee (organization) responsibilities to the club", the observed variables in each item on the load conditions are shown in table 1.

According to the factor loading conditions in table 1, this study eliminated the corresponding item of the lower load in the four items ( $\mathrm{Y} 13=0.292 ; \mathrm{Y} 3=0.292 ; \mathrm{Y} 6$ $=0.224$; Y12 $=0.213$.). After new factor analysis of the modified questionnaire, factor loading are reached more than 4.5. We think that "staff (organization) responsibilities to the club", part of the forecast questionnaire, is acceptable. Prepare the formal questionnaire. "The club (group Woven) responsibility "of the final "sports fitness club employees' psychological contract questionnaire" consists of 15 items, including " economic trade responsibility " (5 items), "career development responsibility “(5entries), “ interpersonal relationship responsibility”(5 entries) ;”Employees responsibility" consists of 16 items, including" economic trade responsibility "(6 items),"career development responsibility"(5 entries), "responsibility of human relationships"(5 entries). Questionnaire forms entries with statements, using the 5 Likert scale score.

Sports Fitness Club of Employees' Psychological Contract Questionnaire's Reliability and Validity Test. Test index and internal consistency coefficient of the sports fitness club of employees' psychological contract questionnaire are shown in table 2 and table 3 . All Cornbahc a coefficients are between 0.662 a 0.895 , to achieve an acceptable level, which indicates that the questionnaire has good reliability. In 
addition, considering the latent variable load of employees' psychological contract three-dimensional structure, we found that "the club (organization) responsibility" and "employee responsibility" contain clear factor structure, within the factors including high factor of the load corresponding to the entries(the "club (organization) responsibility" is averaging 0.45 above, the "employee responsibility" is the more than 0.41), and low error loading, which illustrates the structure of the questionnaire has good reliability and validity. The first hypothesis of the study is confirmed.

\section{Effect of Sports Club's “organizational responsibility" for employee job satisfaction}

Table4 shows that "organizational responsibility" in the eight aspects-compensation satisfaction, promotion satisfaction, managers' satisfaction, Interests' satisfaction, reward satisfaction, colleague satisfaction, work itself satisfaction and communication satisfaction - is significantly positively correlated, is negatively correlated with operating procedures satisfaction. The second assumptions of the study is confirmed.

Table1: The factor loadings in each item of the observed variables of emp loyee's responsibility

\begin{tabular}{cccc}
\hline & Component1 & Component2 & Component3 \\
\hline Y19 & 0.754 & & \\
Y18 & 0.733 & & \\
Y20 & 0.823 & & \\
Y14 & 0.675 & & \\
Y16 & 0.527 & & \\
Y15 & 0.517 & & \\
Y13 & 0.292 & & \\
Y9 & & 0.724 & \\
Y2 & & 0.681 & \\
Y1 & & 0.579 & \\
Y5 & & 0.523 & \\
Y4 & & 0.518 & \\
Y3 & & 0.294 & \\
Y6 & & 0.224 & \\
Y10 & & & 0.782 \\
Y11 & & 0.696 \\
Y7 & & & 0.629 \\
Y17 & & & 0.514 \\
Y8 & & & 0.507 \\
Y12 & & & \\
\hline
\end{tabular}

Table 2: The mean, standard deviation, questionnaire validity analys is of each measurement table (2)

\begin{tabular}{ccc}
\hline Each scale & $\mathrm{M}(\mathrm{SD})$ & Cronbach a \\
\hline Club responsibility to their employees & $4.641(0.8127)$ & 0.935 \\
Economic trade responsibility & $4.730(0.7534)$ & 0.751 \\
Career development responsibility & $4.746(0.7999)$ & 0.903 \\
Interpersonal responsibility & $4.284(0.8715)$ & 0.827 \\
\hline
\end{tabular}


Table 3: The mean, standard deviation, questionnaire validity analys is of each measurement table (3)

\begin{tabular}{ccc}
\hline Each scale & $\mathrm{M}(\mathrm{SD})$ & Cronbach a \\
\hline Club responsibility to their employees & $4.211(0.6795)$ & 0.917 \\
Economic trade responsibility & $4.238(0.7564)$ & 0.706 \\
Career development responsibility & $4.540(0.6544)$ & 0.893 \\
Interpersonal responsibility & $4.149(0.6891)$ & 0.735 \\
\hline
\end{tabular}

Table 4:the spearman correlation between organizational responsibility and seven dimensions of emp loyees' job satisfaction

\begin{tabular}{cllccccccc}
\hline & $\begin{array}{l}\text { Compen } \\
\text { sation } \\
\text { satisfacti } \\
\text { on }\end{array}$ & $\begin{array}{l}\text { Compen } \\
\text { sation } \\
\text { satisfacti } \\
\text { on }\end{array}$ & $\begin{array}{c}\text { Manag } \\
\text { ers } \\
\text { satisfa } \\
\text { ction }\end{array}$ & $\begin{array}{c}\text { Interes } \\
\text { ts } \\
\text { satisfa } \\
\text { ction }\end{array}$ & $\begin{array}{c}\text { Rewar } \\
\text { d } \\
\text { satisfa } \\
\text { ction }\end{array}$ & $\begin{array}{c}\text { Operat } \\
\text { ing } \\
\text { proced } \\
\text { ures } \\
\text { satisfa } \\
\text { ction }\end{array}$ & $\begin{array}{c}\text { Collea } \\
\text { gue } \\
\text { satisfa } \\
\text { ction }\end{array}$ & $\begin{array}{c}\text { Job } \\
\text { satisfa } \\
\text { ction } \\
\text { in } \\
\text { itself }\end{array}$ & $\begin{array}{c}\text { Commun } \\
\text { ication } \\
\text { satisfactio } \\
\text { n }\end{array}$ \\
\hline $\begin{array}{c}\text { Organiza } \\
\text { tional } \\
\text { responsi } \\
\text { bility }\end{array}$ & $0.562^{*} *$ & $0.571^{* *}$ & $\begin{array}{c}0.534^{*} \\
*\end{array}$ & $\begin{array}{c}0.516^{*} \\
*\end{array}$ & $\begin{array}{c}0.522^{*} \\
*\end{array}$ & -0.435 & $\begin{array}{c}0.514^{*} \\
*\end{array}$ & $\begin{array}{c}0.539^{*} \\
*\end{array}$ & $0.565^{* *}$ \\
\hline
\end{tabular}

Note: “*”said $\mathrm{P}<0.01$

\section{The Forecast Effect of "Organizational Responsibility" on Employees' Job Satisfaction}

Based on '3.2.1", this study further discusses the impact of different aspects of "organizational responsibility" on employee job satisfaction. By using multiple regression analysis, the independent variables are the three dimensions of organizational of responsibility-the economic trade responsibility, career development responsibility and interpersonal responsibility; the nine dimensions of employee job satisfaction - the compensation satisfaction, promotion satisfaction, Managers' satisfaction, Interests' satisfaction, reward satisfaction, operating procedures' satisfaction, colleague satisfaction, job satisfaction in itself and social satisfaction - are dependent variables.

Results show that the predictive power of "economic trade responsibility" and "career development responsibility" to compensation satisfaction reached significant level, which had a significant positive impact. Meanwhile, the predictive power of "interpersonal relationship" predictive power to compensation satisfaction reached significant level, which had a significant negative impact. "Economic trade responsibility", "career development responsibility" and "interpersonal responsibility" for the promotion satisfaction was significant predictive power, which had a significant positive impact. Predictive power of "economic trade responsibility", "career development responsibility" and "interpersonal responsibility" to managers" satisfaction reached significant level, namely a positive effect. Among them, "economic trade responsibility" and "interpersonal responsibility" for interests' satisfaction was significant predictive power, namely a positive influence. Among them, the predictive power of "career development responsibility" to interests' satisfaction reached significant level, that was a significant negative impact.

The predictive power of "economic trade responsibility", "career development responsibility" and "interpersonal responsibility" to reward satisfaction was 
significant, that was a significant positive impact. "Economic trade responsibility" for procedures satisfaction was significant predictive power, namely a significant positive impact. The predictive power of "economic trade responsibility" to operating procedures' satisfaction reached significant level, which was a significant influence, In the meantime," career development responsibility" and "interpersonal responsibility" for operating procedures' satisfaction was significant predictive power, that had a significant negative impact. "Economic trade responsibility", "career development responsibility" and "interpersonal responsibility" for the colleague satisfaction was significant predictive power, that had a significant positive impact. Among them, the predictive power of "economic trade responsibility" and "career development responsibility" to work itself satisfaction reached a significant level, that had a significant positive impact. Among them, the "interpersonal responsibility" for the interests' satisfaction was significant predictive power, which had a significant negative impact. "Economic transactions responsibility", "career development responsibility" and "interpersonal responsibility" for communication satisfaction was significant predictive power, which had a significant positive impact.

\section{Conclusion}

(1)About the set of the items and the structure of content, the "organization responsibility parted questionnaire" and the "employee responsibility parted questionnaire" of the "sports fitness club employees' psychological contract questionnaire" worked out by the study are reasonable.

(2)"Organizational responsibility" in the eight aspects - the compensation of employee's satisfaction, promotion satisfaction, management satisfaction, benefits satisfaction, reward satisfaction, colleague satisfaction, work itself satisfaction and communication satisfaction-is significantly positively correlated, is negatively correlated with operating procedures satisfaction.

(3)Effect "organizational responsibility" for employee job satisfaction mainly in the following three aspects. First, to the nine aspects-compensation satisfaction, promotion satisfaction, managers' satisfaction, Interests' satisfaction, reward satisfaction, colleague satisfaction, work satisfaction in itself, operating procedures satisfaction and communication satisfaction-"economic trade responsibility "has prediction effect, and there is significant positive correlation. Second, "career development responsibility" has predictive effect to the seven aspects-compensation satisfaction, promotion satisfaction, managers' satisfaction, reward satisfaction, work satisfaction in itself ,operating procedures satisfaction and communication satisfaction, which is significant positive correlation. But there is a significant negative impact on interests' satisfaction and colleague satisfaction. Third, to the six aspects-promotion satisfaction, managers' satisfaction, Interests' satisfaction, reward satisfaction, colleague satisfaction and communication satisfaction- "interpersonal responsibility" has predictive effect, and there is significant positive correlation. For compensation satisfaction, work satisfaction in itself and communication satisfaction, there exists significant negative correlation

\section{References}

[1] Guest E.D.. On Meaning, Metaphor and Psychological Contract: A Response to Rousseau [J].Journal of Organizational Behavior, 1998, 19:673-677.

[2] Llewellyn N..The Roleof Psychological Contracts Within Internal Service 
Networks [J].The Service Industries Journal, 2001, 21(1):211-226.

[3] Lusch R.F., Brown J.R..Interdependency, Contracting, and Relational Behavior in Marketing Channels [J].Journal of Marketing, 1996, 60(4):19-38.

[5] Rousseau D.M..New Hire Perception of Their Own and Their Employer's Obligations: A Study of Psychological Contracts [J].Journal of Organizational Behavior, 1990,11 (5):389-400.

[6] Guest E.D.On Meaning, Metaphor and Psychological Contract: A Response to Rousseau [J].Journal of Organizational Behavior, 1998, 19:673-677.

[7] Robinson S L, Kraatz M S, Rousseau D M. Changing obligations and The psychological contract: A longitudinal study [J].Academy of Management Journal, 1994, 37:137-152.

[8] Rousseau, D.M. The "Problem" of The Psychological Contract Considered [J].Journal of Organizational Behavior, 1998, 19:649-664.

[9] Robinson, S.L.Trustand Breach of The Psychological Contract [J].Adminis trative ScienceQuarterly,1998,41:574-599.

[10] Thompson J.\& Bunderson S., "Violations of Principle: Ideological Currency In The Psychological Contract'[J],Academy of Management Review,2003Vol.(28): 571-585.

[11] Kickul J, Lester S W, FinkI J.Promise breaking during radical organizational change: do justice interventions make a difference [J], Journal of organizational behavior,2002,23:469-488. 